\title{
Everybody Loves Cinderella; a Study on Boosting Students' Motivation in an Indonesian EFL Classroom
}

\author{
Fauziatul Husna \\ Univeristy of Indonesia \\ E-mail: nji4711@gmail.com
}

Doi:10.7575/aiac.alls.v.4n.2p.16

URL: http://dx.doi.org/10.7575/aiac.alls.v.4n.2p.16
Received: 03/04/2013

Accepted: 03/06/2013

\begin{abstract}
Motivation is by large a fundamental aspect in learning foreign languages which plays significant role in determining the outcome of the learning process. For more than a decade now, EFL in Indonesia have been in the stagnant period when various efforts could not result as expected. One of the problems is that those efforts often do not deal with the real problem in the real classroom practice. This paper reports on classroom application was conducted in order to boost students' motivation by using project-based learning as well as peer-learning strategy. Students were assigned to produce a play from scratch within their respective groups. By the end of the semester, each group of students has to present the play as their final assessment in English subject.
\end{abstract}

Keywords: motivation, project-based learning, role play

\section{Introduction}

In any language teaching and learning programs, there are three aspects that create and shape the flow of the process; methodology, teachers, and learners. All these three aspects work together in forming a teaching and learning process and at the end, defining its success. However, aside from the effort to upgrade teachers' qualification, most efforts and researches in language teaching field have been wandering around the question about how to make students reach their highest potentials in learning by solely seek for the best method to transfer the knowledge to students without bothering to pay enough attention to the other aspect involved. Many believe, this mere ignorance is what leads language teaching into the worrying condition it is today.

With that new realization in mind, many teaching experts are trying to shift the focus of language teaching and learning to the learners. Above all, they are the very reason why the language learning classrooms are so moving that there are no two foreign language classes are ever the same (Tarone and Yule, 1991). Since the emergence of the focus-onlearners trend in the early 1980's, teachers and instructors all over the globe have been made to match their methods and materials to their students' needs and preferences. However, it is not yet giving the best possible result due to another kind of ignorance. This time, the focus is all given to the cognitive aspects of learners while the affective aspects are being put aside.

Since the time before the World War I, cognitive aspects had been proposed as the most important factor for students to be successful in their study. Then was the time when the intelligence tests first become the prerequisite for everyone who wish to get into any school or academy both in civil and military service. It was also at that same time that such terms like genius, above average intelligence, average and mentally deficient emerged. Those terms ever since become the label who generally describe students as a whole unit; the labels show the world who they really are. With such kind of paradigm, people accept it as fine that heredity is all that matters in deciding whether someone will be a successful or not. That was indeed kind of silly that many opposed that theory in the name of another aspect that influences human ability to think, that was affective aspect or affective intelligence.

This theory about affective aspects finally aroused because of the findings revealed in some researches that most successes of students are not solely thanks to their cognitive intelligence, but rather a combination of the cognitive and affective intelligence. Affective intelligence consists of personality, motivation, confidence and some other individual aspects that will eventually influence how people live their life.

However, one most noticeable feature in affective aspects that draw much attention is motivation. Various studies have been done to find out about what the role of motivation in learning is and how to make that role works to promote better result of learning. It is clear that motivation plays a huge role in learning process. It goes without saying that students who are lack of motivation will find it hard to go on trying to achieve enough, let alone to reach their best potentials. Less motivated students usually have no idea of what they are doing and also what this all for. They tend to be so ignorant that teachers will find it impossibly hard to push them to put more effort into their learning.

In any given situation, teaching a language is never an easy task. Teaching English as a foreign language means that the teachers have to familiarize the language and its whole set of grammatical system and sociological aspects to students 
who do not use English even as their second language. So, the pressure is much greater for teachers that the problem like lack of motivation students will definitely need to be resolved in order for the teaching purpose to be achieved.

\subsection{What is motivation?}

In the general sense, motivation is the push that encourages people to do something in their lives. This push make anything they are doing become a lot easier since it gives them strength. It gives reasons of why they have to do or not to do things. Most of the time, it is the reason itself that become the motivation. With that definition, it is safe to say that motivation is the very key of an act since no act will be accomplished without the presence of any.

Huitt W. (2001) provides some definition of motivation suggested in various psychology textbooks;

- internal state or condition that activates behavior and gives it direction;

- desire or want that energizes and directs goal-oriented behavior;

- influence of needs and desires on the intensity and direction of behavior.

From those definitions, a conclusion can be drawn that motivation is the desire that energizes any will in people's mind so that their activities will be well directed and focused. By having motivation, people will find it easier to carry on their want. In other word, motivation gives people power to stay and survive in their struggle in accomplishing their goal.

\subsection{Motivation in Learning Process}

Motivation in the classroom is an essential component of teaching. Without the presence of any, the teaching and learning process will be a huge failure since motivation involves a student's desire to participate in the learning process. It makes sense because the participation of the students is one of the key ingredients of a good language learning classroom. It is also concerned with the reasons or goals which underlie a student's participation in learning activities (Lumsden, 1994).

Motivation can be either intrinsic or extrinsic in its source. Wagner (2002) presents opinions of Woolfolk (2001) that describes intrinsic motivation as involving internal, personal factors such as needs, interests, curiosity, and enjoyment. A student who is intrinsically motivated undertakes an activity "for its own sake", because the activity itself is rewarding (Lumsden, 1994; Woolfolk, 2001). In contrast is extrinsic motivation, in which the student engages in an activity in order to obtain a reward, or to avoid a punishment. This student is not really interested in the activity for its own sake, but rather for what it will gain them (Woolfolk, 2001).

Moreover, Weiner (2001) propose two types of motivation theories that he calls as intrapersonal and interpersonal theories of motivation. Actually, these two theories are pretty similar with the previous intrinsic and extrinsic motivation, but Weiner emphasize his discussion in the process of motivation emergence. For example, when a student got a bad mark or failed his exam. He will feel the blended emotions that include self-esteem, guilt, and shame. This self-directed feeling and thought comprise what he calls as intrapersonal theory of motivation. On the other hand, with the same situation, the feelings and thoughts from others of whether he is good or bad, responsible or not responsible. That judgment from others is what comprise his interpersonal theories of motivation.

In language learning, to be exact, both of intrinsic and extrinsic motivation are needed. If a student is not motivated to learn, even the most talented and experienced teacher will face difficulty in helping the child achieve their fullest potential. Understanding the various factors which influence motivation will assist teachers in developing strategies for encouraging motivation in the classroom.

\subsection{Less-motivated Students and the Causes}

There are several things that cause the lack of motivation in students. These causes vary from the teachers' side, students' side and also the materials given.

\section{- From teachers' side}

In the learning process, the role of teachers is much more complicated than the simple facilitator term implied. Teachers have to be anything the students need. In an advance classroom with bright students, they have to be good partners with whom those excellent students can study and work together with. However, in a classroom where the students are mostly dependent, they have to be the leaders that organize all the activities in the classroom. So, teachers are supposed to be the organizers who have to ensure that learning process run well.

Unfortunately, in some cases, teachers are the ones who make their students become less motivated. Here is how:

Teachers do not give enough encouragement through reward and compliment when they students succeed in their task. In the opposite way, they always give more than enough lectures contain bad words and anger when the students do mistakes. This behavior is clearly against the consensus belief that encouragement works better than insult in motivating people to do things.

\section{- From students' side}

As proposed by the communicative approach, students are the center of the learning process. It means that the students have to be proactive in the process to reach the best result of their study. Needless to say, if they do 
not play that role well, motivation is far away from them. In addition, their inner self-esteem and confidence have a lot to do with their deficit in motivation and then in achievement.

In Student Motivation (2001), Van Laar argues a theory called self-esteem theory which essentially argues that low self-esteem will lead to low motivation. She proposes that theory based on the factual phenomenon in many schools in USA. There, she finds out that black American students who are really lack in motivation are the ones who also have low self-esteem in regard to their background and appearance. It has been a common knowledge that minority group students always feel that they are less than their White American peers.

A relevant point to this matter that also has to be considered here is the different culture enhances different level of motivation and thus different level of achievement. For example, in USA, the number of white students who accomplish outstanding learning result is much higher compared to the number of those students of black and Asian students. In the smaller scope, writer sees that students in the cities are likely to have more motivation than those students in the suburb. It makes the effort to increase students' motivation in the suburb area is a lot harder than it is in the cities.

\section{- Materials}

One principle in designing good learning materials is matches the materials to the need and proficiency of students. Other way, it will cause a space between students and learning materials that makes full understanding and mastering impossible. In most cases, materials given to the students are far too complicated to their level of ability. This is the very cause of lack of motivation viewed from the materials given. Logically, it can be illustrated this way:

When a student cannot understand the materials about generic structure of descriptive text, it will too risky to ask them to write their own descriptive text. So, when the teacher insists on giving him such kind of task, he will immediately loss his interest and think that it will be much easier for him not to even try.

All of those points above contribute in creating lack of motivation in students. As the result, those students have no willingness and desire to get involved in the learning process whatsoever. The symptoms of this problem can vary depend on how bad the lack of motivation in a student is. In most classrooms, however, some of the symptoms are:

a. Do not bother paying attention to teachers' explanation

b. Do not feel obliged to do the task or even homework

c. Always look bored and sleepy during the class

d. Do not have guilty feeling when the teacher gets angry at them

At the end, teachers cannot expect them to get good mark. What makes I even worse is that some of those students are in fact the smart ones. However, their potentials are buried on their ignorance and lack of motivation.

\subsection{What have been done?}

So far, the importance of motivation or the bad effect of students having lack of motivation has been explained intensely. The question aroused afterward is what kind of treatment has been done to deal with that? In my personal opinion, not much. The majority of teachers, school administer and parents spend all of their time worried about whether the students have enough cognitive intelligence to achieve their learning objectives. The worse thing is that when they do concern about motivational problem in students, instead of considering about how context create and sustain this problem, they self-acclaim that those students are having some psychological problem of having disadvantage background.

Along with that, in their article, Martin L. Maehr and Ryoko Yamaguchi state, "too little attention has been given to how schools as a presumed critical context for fostering achievement can create motivation and achievement orientation of students regardless of the sociocultural context they experience in their extra-school lives." By that statement, both of them actually raise optimistic view that school or teachers in this context can do a vast support in increasing students' self-motivation no matter what kind of life they live outside the classroom. It has something to do with the theory that proposes internal or intrinsic motivation is stronger and last longer than extrinsic motivation from others.

However, fact shows that teachers, as the front men in the effort to increase students' motivation are doing less than enough to reach that goal. Most of the time, teachers act as customers that wish to be served well by their students in the learning situations. For example, teachers want their students to have a great performance in a task no matter what. From my experience, most teachers tend to get angry all the time to those less-motivated students in learning process, but when they get low grade on exams, the teachers let them take all the blame. With that kind of treatment, it is not necessarily appropriate for those teachers to hope the best from their students.

If the learning result is to be increased, that kind of treatment has got to stop immediately. What needed by students to have more motivation is not teacher who blame them for their failure, but the one who can show them and facilitate them a way to possess the motivation.

\section{The Project}

In any EFL classroom, using peer-teaching and peer-learning have become a hit since the emergence of Communicative Language Teaching (CLT). In that case, peer-learning is used to ensure that all students have the same opportunities to use language in group as the implementation of the communicative aspect of learning process. Today, many schools and 
language institutions are promoting instructional method involving active learning in which many chances to formulate their own questions, discuss issues, explain their viewpoint, and involve in cooperative learning by working in teams on problems and projects are presented to the students. Still, this instructional method is a form of peer-learning.

Peer learning is a kind of cooperative learning that enhances the value of students-students interaction and results in various advantageous learning outcomes. In this article, writer focuses on the advantage it gives in increasing the motivation of students in learning. Writer used this strategy in dealing with less-motivated students in SMP 1 Batang Anai in order to help them reach better result in their study of English. However, before the description of the application explained, it has to be noted that there are several considerable points to organize a successful peer learning (Alice Christudason, 2003). They are:

a. teachers must provide intellectual scaffolding

b. teachers have to ensure that presents topics that students are likely to have some relevant knowledge about

c. teachers push students to have more sophisticated level of thinking by giving questions/issues

d. teachers make sure that all students are meaningfully engaged in the collaboratice process.

By referring to those points above, writer have done this strategy in three classes of the $8^{\text {th }}$ grade in SMP 1 Batang Anai. These three classes are chosen because the writer teaches them thus it will be much easier to evaluate the progress and to measure the result of this strategy. Aside from that, there is no special reason why those classes are chosen since all classes are generally having similar level of language proficiency. Peer learning activities can be in the form of role-play, debated, case studies and other exciting and effective teaching strategies that stir students' enthusiasm and encourage peer learning. At the end, students are expected to have more motivation in studying since the process is fun and enjoyable. At this particular study, the form of peer learning used is role play, more specifically a Cinderella story role play.

"Role-plays are very important in the Communicative Approach because they give students an opportunity to practice communicating in different social contexts and in different social roles." (p. 137, Larsen-Freeman). This statement relates role play to communicative approach which emphasize on the language practice and also the context use of language. It means that role play is indeed a right choice to create an atmosphere in which students will be encouraged to get involved. This desire of involvement is what will increase their motivation in learning process.

In addition, McCaslin (1995) introduced role play as having the following characteristics:

It (role play) refers to the assuming of a role for the particular value it may have to the participant, rather for the development of an art....Role playing is what the young child does in a dramatic play, but it is also a tool used by psychologists and play therapists....According to Richard Courtney (1974), "Play, acting and thought are interrelated. They are mechanisms by which the individual tests reality, gets rid of his anxieties, and masters his environment." (p.177)(p.10)

In one article, Yuang states very soecificly about the benefit of using role play in the EFL classroom, "Role play is really a worthwhile learning experience for both the students and the teacher. Not only can students have more opportunities to "act" and "interact" with their peers trying to use the English language, but also students' English speaking, listening, and understanding will improve. Role play lightens up the atmospheres and brings liveliness in the classes. Students learn to use the language in a more realistic, more practical way. Thus they can become more aware of the usefulness and practicality of English. Role play is indeed a useful teaching technique which should be experimented and applied by ESL/EFL teachers more often in the ESL/EFL classrooms."

All of the experts' opinions above are what encourage the writer to use this particular strategy in maintaining peer learning activity that hopefully will result in the increasing motivation in students.

At the beginning, it was a little hard to even catch students' attention in the classroom learning process. They were busy doing everything that have nothing to do with the lesson; gossiping, running, teasing friends and a dozen other distracting activities while writer were trying to explain the use of notice text. Writer literally had to shout and scream to make them remember that they are in the middle of a class. It was terribly frustrating to deal with that kind of students four days a week. The simplest way to explain that mess is "trying to feed people who do not want to eat, while in fact they are starving". From that experience, writer finally come to the conclusion that there is no other way than to make them want to study, make them realize that they need it, means to make them have the motivation to study.

Then, almost miraculously, an opportunity show itself in the form of an offer from the principal to show a performance in the farewell party celebration for the senior class. It gives additional push for the students to join the Cinderella project since they will get to present it in front of the whole school. I was actually worried that it would give extra pressure but turn out I did not really understand how they young minds work. So in the end I got many more applications submitted than I ever expected and we need to make some modification to the story to make it suit our large casts.

The procedure of peer learning by using role play done by the writer was organized as follow:

1. Writer reviewed the materials about narrative text

2. Writer explained role play and how it is different from storytelling that they have been taught before 
3. In each of the classes, writer divided the students into several groups of 5-6 person. Writer ensured that there is a balance of students with high and low motivation in each group

4. Each group was given a narrative Cinderella and asked to perform it in the upcoming week

5. In preparing their performance, students work together in the groups and try to maintain a good group work.

6. After the performance, students from other groups are asked to give comments and critique about the group performance.

7. The best performers are selected to perform a version in front of the whole school on the seniors' graduation.

The procedure took six meetings to get through. It was quite amazing to see them so concern about their performance, especially those students who are usually less motivated in anything related to studying. In the grading, some of those who used to be in the low end of the class surprisingly got high mark. Over all, all of the students are greatly excited about the whole project of the role play performance. They eventually refreshing their image of English and found that there are fun things that included in this subject aside from the boring and complicated grammar lesson. After that role play activity, most of them were found to be more active and interested in the classroom learning process and they got relatively higher grade in the next test held by writer about narratives.

Research indicates that peer learning activities typically result in: (a) team-building spirit and more supportive relationships; (b) greater psychological well-being, social competence, communication skills and self-esteem; and (c) higher achievement and greater productivity in terms of enhanced learning outcomes. From those result of peer learning, not all have been achieved in writer's short-term peer learning application in her classroom. However, a significant progress has appeared and is ready to be continued.

\section{Conclusion}

Students with high motivation are those who will achieve the highest result in learning. Teachers are the ones who can help them in increasing their motivation in various ways and methods. One of those is to use peer-learning, like have been described in this paper, specifically role play activities which allow students to interact with their peer to share interest and motivation they have. This strategy is bound to be successful in increasing students' motivation and then result in better understanding and higher grade in their test.

Being a teacher is probably not a dream job which gives us a fancy life like being a lawyer does. Nor does it guarantee that everyone will look at us with respect and admiration like they do to doctors. However, it is a common knowledge that most teachers do not regret their job and in fact cannot imagine living their lives in any way other than teaching. They know that there are many easier ways to earn a living, but it is unlikely that they will give up their job and then choose one of those ways instead. That is because teaching gives them a right to reach into many lives of others and provide them a power to change those lives to become better. The first step to do so is by increasing their motivation to want that better lives.

\section{References}

Christudason, A. (2003). Peer- Learning. Retrieved from http://www.cdtl.nus.edu.sg/success/sl37.htm Davis, B. G. (1999). Motivating Students in Tools For Teaching, University of California, Berkeley. Retrieved from http:/honolulu.hawaii.edu/intranet/committees/FacDevCom/guidebk/teachtip/motiv.htm

Huang, I. Y.(2008). Role Play for ESL/EFL Children in the English Classroom in The Internet TESL Journal, Vol. XIV, No. 2, February 2008. Retrieved from http://iteslj.org/Techniques/Huang-RolePlay.html

Huitt, W. (2001). Motivation to learn: An overview. Educational Psychology Interactive. Valdosta, GA: Valdosta State University. Retrieved [date], retrieved from http:/www.edpsycinteractive.org/topics/motivation/motivate.html Jasyang. J. (2009). Student motivation is entirely the responsibility of the teacher? Retrieved from http://www.teachingenglish.org.uk/blogs/jasyang1101/student-motivation-entirely-responsibility-teacher Kodotchigova, M. (2002) Role Play in Teaching Culture: Six Quick Steps for Classroom Implementation. The Internet TESL Journal, Vol. VIII, No. 7, July 2002. Retrieved Sep. 1, 2007, from http://iteslj.org/Techniques/KodotchigovaRolePlay.html

Maehr, M. L., Ryoko, Y. (2001).Cultural Diversity, Student Motivation and Achievement. In F. Salili, Chi-yue Chiu and Ying-yi Hong (Eds), Student Motivation, pp. 123-148. New York: Plenum Publishers

Reid, S. (2011). Factor that Influence Students Motivation in the

Classroom.http://www.ehow.com/facts_7717205_factors-influence-student-motivation-classroom.html

Tarone, Elaine and George Yule. 1991. Focus on the Language Learner. Oxford: Oxford University Press.

Van Laar, C. (2001).Declining Optimism in Ethnic Minority Students: The Role of Attribution and Self-Esteem. In F. Salili, Chi-yue Chiu and Ying-yi Hong (Eds), Student Motivation, pp. 79-104. New York: Plenum Publishers Wagner,D. (2002). Student Motivation and Parental Involvement. Retrieved from http://csmstu01.csm.edu/st03/dwagner/new_page_2.htm

Weiner, Bernard.(2001).Intrapersonal and Interpersonal Theories of Motivation from an Attribution Perspective. In F. Salili, Chi-yue Chiu and Ying-yi Hong (Eds), Student Motivation, pp. 17-30. New York: Plenum Publisher Weller, Matthew. General Principles of Motivation. Los Angeles Business Journal, March 14, 200 retrieved from http://honolulu.hawaii.edu/intranet/committees/FacDevCom/guidebk/teachtip/motivate.htm 